\title{
Pengolahan Bekatul dan Spirulina Menjadi Cookies Kaya Protein
}

\section{The Processing of Rice Bran and Spirulina into Protein Rich Cookies}

\author{
Diki Danar Tri Winanti ${ }^{1 凶}$, Susilawati ${ }^{1}$ Zulferiyenni $^{1}$ \\ ${ }^{1}$ Jurusan Teknologi Hasil Pertanian, Fakultas Pertanian, Universitas Lampung \\ Komunikasi Penulis, email: dikiwinanti@fp.unila.ac.id \\ DOI:http://dx.doi.org/10.23960/jtep-l.v10i3.309-316 \\ Naskah ini diterima pada 25 Juni 2021; revisi pada 3 Agustus 2021; \\ disetujui untuk dipublikasikan pada 17 Agustus 2021
}

\begin{abstract}
The rice bran and spirulina are Indonesia's local product that have high nutritional content. Their postharvest with processed it to cookies hoped to enhance diversification of rice bran and spirulina in order to increase people's nutritional intake. The purpose of the study was to study the postharvest of rice bran and spirulina to cookies with rich of protein. This research used Completely Randomized Design (CRD) method and the advanced test Duncan Multiple Range Test (DMRT) with four treatments of cookies was $13.3 \%, 11.1 \%$, 8.8\%, and 6.6\% rice bran. The analysis used proximate tests (water content, proteins, fat, and ash) and hedonically sensory tests (color score, aroma, taste, texture, and overall acceptance). The best cookies were 11,1\% concentration of rice bran. Their chemical properties were $3.34 \%$ water content, $7.26 \%$ protein, $37.2 \%$ fat, and $47.01 \%$ carbohydrates that have filled up the National Standart of Indonesia (SNI) of biscuits whereas ash content $4.31 \%$ exceeds the maximum limit. The sensory characteristics of coockie was neutral color, neutral aroma, rather fond taste, liking texture, and overall like.
\end{abstract}

Keywords : cookies, rice bran, rich protein, sensory analysis, spirulina

\begin{abstract}
ABSTRAK
Bekatul dan spirulina adalah hasil bumi lokal Indonesia yang memiliki kandungan gizi yang tinggi. Pengolahan keduanya menjadi cookies diharapkan dapat memperkaya diversifikasi bekatul dan spirulina dalam rangka peningkatan asupan gizi masyarakat. Tujuan dari penelitian ini adalah untuk mengkaji pascapanen bekatul dan spirulina yang diolah menjadi cookies kaya protein. Penelitian menggunakan Rancangan Acak Lengkap (RAL) dan uji lanjut Duncan Multiple Range Test (DMRT) dengan empat perlakuan cookies bekatul spirulina yang diuji yaitu konsentrasi bekatul 13,3\%,11,1\%, 8,8\%, dan 6,6\%. Analisis yang dilakukan antara lain uji proksimat (kadar air, protein, lemak, dan kadar abu) dan uji sensori secara hedonik (warna, aroma, rasa, tekstur, penerimaan keseluruhan). Cookies bekatul spirulina dengan hasil terbaik yaitu cookies dengan konsentrasi bekatul 11,1\%. Karakterisik kimianya berupa kadar air 3,34\%, protein 7,26\%, lemak 37,20\%, dan karbohidrat 47.01\% yang telah memenuhi SNI biskuit sedangkan kadar abu 4,31\% melebihi batas maksimum SNI. Karakteristik sensorinya warna netral, aroma netral, rasa agak suka, tekstur suka, dan secara keseluruhan tampilan agak suka.
\end{abstract}

Kata Kunci : bekatul, cookies, kaya protein, uji sensori, spirulina

\section{PENDAHULUAN}

Cookies adalah salah satu jenis biskuit dari adonan lunak dengan kadar lemak tinggi dan ketika dipatahkan terasa renyah karena penampang potongnya bertekstur kurang padat (BSN, 1992). Bekatul adalah hasil samping penggilingan padi khususnya pada proses penyosohan kedua. Kandungan gizinya yang kaya akan karbohidrat, serat pangan (dietary fiber), protein, lemak, vitamin, dan mineral membuat bekatul tidak kalah bernilai dibandingkan tepung terigu. Aktivitas antioksidan total bekatul dengan uji DPPH setara dengan kemampuan 28,74 kali vitamin C (Damayanthi et al., 2010). Namun, dengan 
kandungan lemaknya yang tinggi, bekatul mudah tengik (offflavor) karena oksidasi lemak. Proses pemanasan dapat menonaktifkan enzim lipoksigenase pada bekatul sehingga ketengikan dapat diminimalisir (Astawan dan Febrinda, 2010).

Spirulina $s p$. adalah salah satu bahan pangan fungsional yang memberikan banyak efek baik pada kesehatan. Selain memberi asupan energi dan gizi, pangan fungsional dapat meningkatkan kekebalan tubuh masyarakat (Christwardana et al., 2013) khususnya sejak terjadi pandemi Covid-19. Spirulina sp. khususnya Spirulina plantesis dikenal sebagai salah satu alga hijau biru jenis cyanobacteria berbentuk spiral, spirulina sering digunakan sebagai bahan pangan super food. Kandungan makro dan mikronutriennya yang tinggi meliputi protein, pigmen klorofil a, fikosianin, lemak, karotenoid, asam lemak esensial g-linolenic acid (GLA), steroid, vitamin C, vitamin E, zat besi, kalsium, kromium, tembaga, magnesium, mangan, fosfor, kalium, natrium dan seng. Sedangkan polisakarida yang terdapat pada dinding selnya memiliki daya cerna $86 \%$ sehingga mudah diserap oleh tubuh (Soni et al., 2017).

Pascapanen spirulina yang biasa digunakan yaitu dengan metode sentrifugasi maupun filtrasi saat pemanenan. Pengeringan dilakukan agar terbentuk kepingan sehingga dapat digiling menjadi tepung yang halus. Selanjutnya, tepung spirulina dapat dibuat menjadi pelet, kapsul, maupun campuran bahan lain (Soni et al., 2017).

Di dunia kesehatan, spirulina diaplikasikan sebagai anti-diabetes (Hu et al., 2019). Pada penelitian Liu et al. (2000) dibuktikan bahwa spirulina dapat menghambat pertumbuhan sel leukimia. Di Afrika dan Amerika, spirulina sudah lama digunakan sebagai makanan tradisional untuk meningkatkan kekebalan tubuh (Susanna et al, 2007). Tingginya kandungan protein dari spirulina juga dapat dimanfaatkan sebagai protein sel tunggal (Phang et al., 2000). Pada perkembangannya, spirulina banyak digunakan sebagai bahan tambahan pembuatan cookies, roti, dan minuman (Christwardana, 2013).

Secara umum, spirulina memiliki flavor dan aroma yang kurang disukai konsumen karena berbau amis. Kenampakannya juga terkadang kurang homogen. Sifat fisik spirulina tersebut dapat diperbaiki dengan metode enkapsulasi maltodekstrin dibantu asam sitrat dengan pengeringan menggunakan spry dryer. Spirulina plantesis hasil enkapsulasi tersebut kemudian diaplikasikan pada produk pangan untuk menambah sifat fungsionalnya namun dengan homogenitas dan profil sensori yang lebih baik (Da Silva et al., 2019).

Penelitian ini bertujuan untuk mengkaji hasil pengolahan bekatul dan spirulina menjadi cookies kaya protein. Harapannya, produk ini dapat memperkaya diversifikasi produk bekatul dan spirulina yang mudah dibuat masyarakat sehingga dapat berkontribusi dalam meningkatkan asupan gizi secara berkelanjutan.

\section{BAHAN DAN METODE}

Bahan pembuatan cookies antara lain spirulina, tepung bekatul, tepung terigu rendah protein, margarin, mentega, susu bubuk, gula semut, dan baking powder.

\subsection{Pelaksanaan Penelitian}

Pembuatan cookies diawali dengan pencampuran margarin, mentega, dan gula semut yang diaduk dengan mixer berkecepatan tinggi hingga adonan mengembang. Susu bubuk, baking powder, spirulina, bekatul, dan tepung terigu protein rendah sedikit demi sedikit ditambahkan dan diaduk dengan spatula hingga merata. Formula setiap perlakuan disajikan pada Tabel 1. Setelah adonan kalis, dilakukan penggilingan hingga pipih dan kemudian dicetak dengan cetakan cookies ketebalan 3-5 mm. Pemanggangan adonan yang sudah dicetak dilakukan dengan oven listrik pada suhu $150^{\circ} \mathrm{C}$ selama \pm 45 menit hingga cookies mudah dilepaskan dari loyang. Cookies yang sudah matang diangkat dan diangin-anginkan hingga panasnya hilang. Cookies disimpan dalam toples kedap udara sehingga kerenyahan dan keawetannya terjaga.

\subsection{Analisis Kimiawi}

Analisis proksimat yang dilakukan berupa uji kadar air, protein, lemak, dan kadar abu (AOAC, 2005) secara duplo. Uji sensori cookies dengan 
Tabel 1. Formula Cookies Bekatul Spirulina

\begin{tabular}{lcccc}
\hline \multirow{2}{*}{ Komposisi Bahan } & \multicolumn{4}{c}{ Perlakuan } \\
\cline { 2 - 5 } & A & B & C & D \\
\hline Bekatul (g) & 60 & 50 & 40 & 30 \\
Spirulina (g) & 10 & 10 & 10 & 10 \\
Tepung terigu protein rendah (g) & 140 & 150 & 160 & 170 \\
Bahan lain (g) & 240 & 240 & 240 & 240 \\
\hline Total (g) & $\mathbf{4 5 0}$ & $\mathbf{4 5 0}$ & $\mathbf{4 5 0}$ & $\mathbf{4 5 0}$ \\
\hline
\end{tabular}

penambahan spirulina dilakukan dengan metode hedonik oleh 30 orang panelis tidak terlatih terhadap atribut warna, aroma, rasa, tekstur, dan kesukaan keseluruhan. Skor yang digunakan dari 1 hingga 7 dimana 1 = sangat tidak suka; 2 = tidak suka; $3=$ agak tidak suka; $4=$ netral; $5=$ agak suka; 6 = suka; 7 = sangat suka.

\subsection{Analisis Data}

Rancangan percobaan yang digunakan pada penelitian ini yaitu Rancangan Acak Lengkap (RAL) dengan perbedaan persentase bekatul pada setiap formula. Sedangkan persentase spirulina adalah $2,2 \%$ yang telah ditetapkan berdasarkan aroma terbaik yang didapatkan (tidak amis) pada saat penelitian pendahuluan (tidak ditampilkan). Analisis statistik menggunakan ANOVA pada software SPSS 17.0 dengan uji lanjut duncan multiple range test (DMRT).

\section{HASIL DAN PEMBAHASAN}

\subsection{Kandungan Kimiawi}

Berdasarkan uji proksimat yang telah dilakukan (Tabel 21), diketahui perlakuan penambahan bekatul tidak memberikan pengaruh nyata $(p<0,05)$ terhadap kadar air, karbohidrat, dan protein. Menurut Kasim et al. (2018), tingginya suhu pemanggangan dapat menyebabkan denaturasi protein menjadi struktur yang lebih sederhana sehingga kadar protein berkurang. Pada pengembangan produk selanjutnya, disarankan untuk menggunakan suhu pemanggangan yang lebih rendah agar protein yang dapat dipertahankan lebih banyak.

Perlakuan diketahui berpengaruh nyata terhadap kadar lemak dan abu. Hal ini disebabkan oleh pengaruh perbandingan tepung terigu dan bekatul dalam adonan. Sifat alami bekatul memiliki kandungan lemak tinggi sehinga sering dibuat menjadi minyak bekatul (Patel and Naik, 2004). Menurut penelitian Wanyo et al. (2009) kandungan lemak dan abu tepung bekatul berturut-turut mencapai $20 \%$ dan $11 \%$ sedangkan tepung terigu hanya $1,25 \%$ dan $0,53 \%$.

Kadar abu dapat merepresentasikan kandungan mineral bahan yang digunakan. Kadar abu cookies mengalami peningkatan dengan adanya penambahan konsentrasi tepung bekatul sebagaimana penelitian Fatkurahman et al. (2012) bahwa substitusi bekatul dapat menyebabkan meningkatnya kadar abu. Menurut SNI 01-2973-1992, batas kadar abu pada biskuit yaitu maksimal 2\%. Cookies bekatul spirulina semua perlakuan menunjukkan kadar abu $>2 \%$ karena terpengaruh oleh mineral dari kandungan spirulina. Ali dan Saleh (2012) memaparkan banyaknya kandungan mineral dalam $100 \mathrm{~g}$ spirulina antara lain potasium 1400 $\mathrm{mg}$, kalsium $700 \mathrm{mg}$, fosfor $800 \mathrm{mg}$, magnesium $400 \mathrm{mg}$, dan zat besi $100 \mathrm{mg}$. Oleh karenanya, spirulina disebut sebagai superfood yang dapat membantu menjaga kesehatan masyarakat.

\subsection{Warna}

Warna makanan menjadi salah satu pendorong keinginan konsumen untuk membeli atau tidak membeli suatu produk. Pada penelitian ini, panelis rata-rata memberikan skor 4-5 yang artinya mereka bersikap netral hingga agak suka terhadap warna cookies bekatul spirulina. Artinya, warna cookies memerlukan perbaikan.

Tabel 3 menunjukkan bahwa perbedaan konsentrasi tepung bekatul tidak memberikan pegaruh yang berbeda nyata karena warna cookies dipengaruhi oleh penambahan spirulina. 
Tabel 2. Hasil Analisis Proksimat Cookies Bekatul Spirulina

\begin{tabular}{|c|c|c|c|c|c|}
\hline \multirow[b]{2}{*}{ Parameter } & \multicolumn{4}{|c|}{ Konsentrasi tepung bekatul } & \multirow[b]{2}{*}{$\begin{array}{c}\text { Syarat Mutu Cookies } \\
\text { menurut SNI }\end{array}$} \\
\hline & $\begin{array}{c}A \\
(13,3 \%)\end{array}$ & $\begin{array}{c}\text { B } \\
(11,1 \%)\end{array}$ & $\begin{array}{c}C \\
(8,8 \%)\end{array}$ & $\begin{array}{c}\text { D } \\
(6,6 \%)\end{array}$ & \\
\hline Kadar air (\%) & 3,92 a & 3,34 a & 3,89 a & $4,91^{\mathrm{a}}$ & Maksimal 5\% ${ }^{1}$ \\
\hline Karbohidrat(\%) & 48,57 a & $47,01^{\text {a }}$ & 47,95 a & $45,72^{\text {a }}$ & - \\
\hline $\operatorname{Protein}(\%)$ & $6,72^{a}$ & $7,26^{\text {a }}$ & $6,80^{\text {a }}$ & $7,24^{\text {a }}$ & Minimal $6 \% 1$ \\
\hline Lemak(\%) & 35,24 a & $37,20 \mathrm{~b}$ & 35,32 a & $38,08 \mathrm{~b}$ & - \\
\hline $\operatorname{Abu}(\%)$ & $5,54^{c}$ & $4,31^{\text {a }}$ & $6,02 \mathrm{~d}$ & $4,92 \mathrm{~b}$ & Maksimal $2 \%^{2}$ \\
\hline
\end{tabular}

Keterangan: ${ }^{1}$ SNI $2973-2011 ;{ }^{2}$ SNI $01-2973-1992$

Tabel 3. Skor Warna Cookies Bekatul Spirulina

\begin{tabular}{|c|c|}
\hline Perlakuan & Nilai Tengah \\
\hline Konsentrasi bekatul 13,3\% & $4,90^{a}$ \\
\hline Konsentrasi bekatul $11,1 \%$ & 4,70 a \\
\hline Konsentrasi bekatul $8,8 \%$ & 5,00 a \\
\hline Konsentrasi bekatul $6,6 \%$ & 5,33 a \\
\hline
\end{tabular}

*) Keterangan: 1 = sangat tidak suka; 2 = tidak suka; 3 = agak tidak suka; 4 = netral; 5 = agak suka; 6 = suka; 7 = sangat suka.

Aplikasi tepung spirulina pada cookies sebanyak $2,2 \%$ dari total adonan menyebabkan warna menjadi hijau muda seperti warna greentea sehingga cukup menarik selera konsumen. Sebagaimana yang dilaporkan oleh Ali dan Saleh (2012) bahwa pigmen spirulina didominasi oleh fikosianin dan klorofil, serta sedikit karotenoid. Namun penambahan konsentrasi tepung bekatul sedikit memudarkan warna hijau dari spirulina pada cookies sehingga warnanya menjadi hijau pucat. Bekatul mengandung senyawa fitokimia yang dapat menyebabkan warna coklat selama pemanggangan (Sarbini et al., 2009).

\subsection{Aroma}

Aroma cookies bekatul dievaluasi untuk mengukur ada tidaknya aroma amis dari spirulina atau tengik dari bekatul yang mempengaruhi tingkat penerimaan konsumen terhadap produk. Tabel 4 menunjukkan bahwa rata-rata panelis memberikan skor antara 4-5 atau netral hingga agak suka sehingga perlu adanya penambahan bahan yang dapat meningkatkan penerimaan aroma cookies bekatul spirulina. Secara umum, perlakuan penambahan konsentrasi tepung bekatul tidak berbeda nyata terhadap aroma cookies karena pengaruh aroma spirulina juga memiliki andil dalam pembentukan aroma.
Baik bekatul maupun spirulina masing-masing memiliki senyawa aromatik yang membentuk flavour khasnya. Aroma bekatul dibentuk oleh adanya komponen volatil minyak tokofenol dan pengaruh reaksi maillard selama pemanggangan (Sarbini, et al., 2009). Aroma spirulina secara alami segar dan sedikit amis khas rumput laut. Pemicu aroma ini antara lain banyaknya garam mineral, 53 senyawa volatil, dan 23 senyawa karbonil yang volatil seperti heptanal dan beberapa keton (Ekantari et al., 2017).

\subsection{Rasa}

Rasa cookies bekatul spirulina secara umum dinilai oleh panelis dengan skor 4-5 atau netral hingga agak suka (Tabel 5). Perlakuan konsentrasi bekatul memperikan pengaruh yang berbeda nyata dengan skor terbaik pada perlakuan B konsentrasi bekatul 11,1\%. Pembentukan rasa adalah akibat adanya reaksi Maillard yang lebih banyak terjadi pada cookies dengan konsentrasi bekatul tinggi sehingga cita rasa yang terbentuk lebih kuat (Sarbini, et al, 2009). Reaksi Maillard pada cookies kemungkinan juga dipengaruhi oleh kandungan asam amino Spirulina yang mencapai $47 \%$ dari total proteinnya (Soni et al., 2017) sehingga membentuk rasa khas yang masih asing bagi panelis. Masih diperlukan perbaikan formula untuk meningkatkan penerimaan rasa dari cookies bekatul spirulina. 


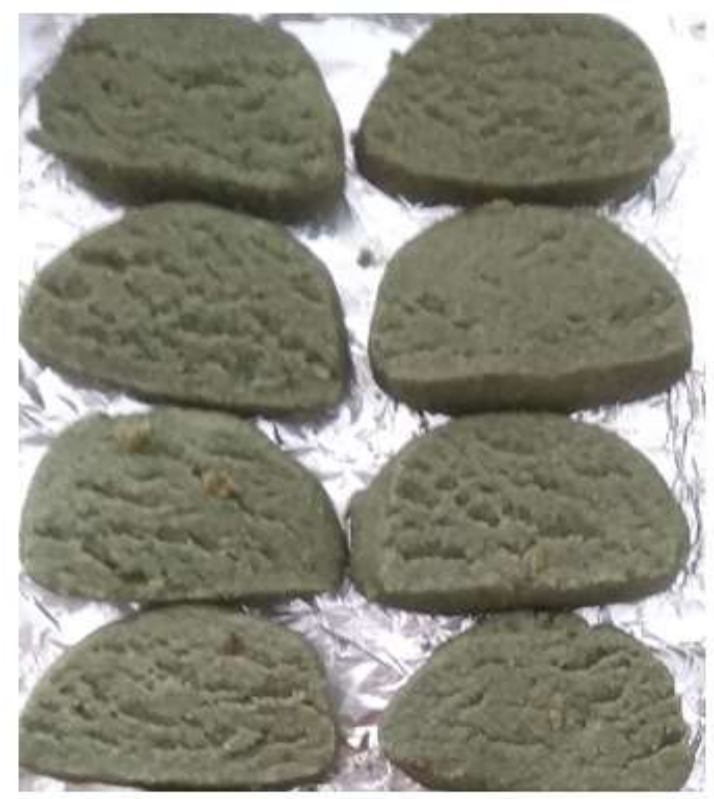

Konsentrasi bekatul 13,3\%

Konsentrasi bekatul 11,1\%

Konsentrasi bekatul 8,8\%

Gambar 1. Kenampakan Warna Cookies Bekatul Spirulina

Tabel 4. Skor Aroma Cookies Bekatul Spirulina

\begin{tabular}{cc}
\hline Perlakuan & Nilai Tengah \\
\hline Konsentrasi bekatul 13,3\% & $4,97 \mathrm{a}$ \\
Konsentrasi bekatul 11,1\% & $4,77^{\mathrm{a}}$ \\
Konsentrasi bekatul $8,8 \%$ & $5,00 \mathrm{a}$ \\
Konsentrasi bekatul $6,6 \%$ & $4,93 \mathrm{a}$ \\
\hline
\end{tabular}

*) Keterangan: 1 = sangat tidak suka; 2 = tidak suka; 3 = agak tidak suka; 4 = netral; 5 = agak suka; 6 = suka; 7 = sangat suka.

Tabel 5. Skor Rasa Cookies Bekatul Spirulina

\begin{tabular}{|c|c|}
\hline Perlakuan & Nilai Tengah \\
\hline Konsentrasi bekatul 13,3\% & $5,20 \mathrm{ab}$ \\
\hline Konsentrasi bekatul 11,1\% & 5,43 a \\
\hline Konsentrasi bekatul $8,8 \%$ & $4,70 \mathrm{ab}$ \\
\hline Konsentrasi bekatul $6,6 \%$ & $4,63 \mathrm{~b}$ \\
\hline
\end{tabular}

*) Keterangan: 1 = sangat tidak suka; 2 = tidak suka; 3 = agak tidak suka; 4 = netral; 5 = agak suka; $6=$ suka; $7=$ sangat suka.

\subsection{Tekstur}

Tekstur cookies yang diukur pada penelitian ini yaitu kemudahan patah ketika digigit yang dapat dideteksi dengan panca indera termasuk pendengaran dan banyaknya remahan yang terbentuk dalam mulut. Tabel 6 menunjukkan bahwa secara umum panelis tidak dapat membedakan tekstur cookies bekatul dengan berbagai perlakuan yang diberikan. Panelis ratarata menilai dengan skor 4 yaitu netral. Pada perlakuan B (cookies dengan konsentrasi bekatul $11,1 \%$ ), panelis memberi nilai 6 atau suka dimana secara statistik data tersebut menunjukkan perbedaan nyata daripada perlakuan lain.

Tekstur cookies dipengaruhi oleh kemampuan penyerapan air adonan yang biasanya dilakukan oleh gluten tepung terigu. Semakin banyak gluten, maka air yang terikat akan semakin banyak. Jika tepung terigu disubstitusi oleh tepung bekatul, maka kandungan gluten dan air yang diserap akan lebih sedikit. Ketika dilakukan pemanggangan maka kandungan air yang sedikit tersebut akan lebih mudah diuapkan (Fatkurahman et al., 2012). Akibatnya, cookies 
Tabel 6. Skor Tekstur Cookies Bekatul Spirulina

\begin{tabular}{cc}
\hline Perlakuan & Nilai Tengah \\
\hline Konsentrasi bekatul $13,3 \%$ & 4,53 a \\
Konsentrasi bekatul $11,1 \%$ & 6,03 b \\
Konsentrasi bekatul $8,8 \%$ & 4,27 a \\
Konsentrasi bekatul $6,6 \%$ & 4,97 a \\
\hline
\end{tabular}

*) Keterangan: 1 = sangat tidak suka; 2 = tidak suka; 3 =agak tidak suka; 4 = netral; 5 = agak suka; 6 = suka; $7=$ sangat suka.

Tabel 7. Skor Penerimaan Keseluruhan Cookies Bekatul Spirulina

\begin{tabular}{cc}
\hline Perlakuan & Nilai Tengah \\
\hline Konsentrasi bekatul $13,3 \%$ & $5,00 \mathrm{ab}$ \\
Konsentrasi bekatul $11,1 \%$ & $5,57 \mathrm{a}$ \\
Konsentrasi bekatul $8,8 \%$ & $4,70 \mathrm{~b}$ \\
Konsentrasi bekatul $6,6 \%$ & $4,80 \mathrm{~b}$ \\
\hline
\end{tabular}

*) Keterangan: 1 = sangat tidak suka; 2 = tidak suka; 3 = agak tidak suka; 4 = netral; 5 = agak suka; $6=$ suka; $7=$ sangat suka.

akan menjadi lebih renyah. Rendahnya skor tesktur pada perlakuan konsentrasi bekatul yang tinggi kemungkinan disebabkan karena tekstur cookies menjadi terlalu mudah hancur sehingga kurang disukai panelis.

\subsection{Penerimaan Keseluruhan}

Secara umum, panelis memberi skor penerimaan keseluruhan pada cookies bekatul spirulina dari 4 (netral) hingga 5 (agak suka). Statistik menunjukkan bahwa perbedaan perlakuan memberikan pengaruh yang berbeda nyata $(p<0,05)$. Perlakuan B (konsentrasi bekatul $11,1 \%$ ) mendapatkan skor tertinggi yaitu 5,57 dengan taraf agak suka. Penerimaan keseluruhan ini dipengaruhi oleh kesukaan panelis terhadap warna, rasa, aroma, dan tekstur cookies bekatul spirulina dimana skor tertingginya terdapat pada sampel perlakuan B tersebut. Sedangkan perlakuan lain cenderung diberi skor rendah dengan taraf netral hingga agak suka. Hal ini menunjukkan bahwa formula cookies bekatul spirulina yang diterima konsumen hanya membutuhkan konsentrasi tepung bekatul sekitar 11\%, tidak kurang maupun tidak lebih. Penggunaan tepung bekatul dengan kombinasi spirulina yang masih jarang diaplikasikan pada cookies membuat panelis masih merasa asing dengan produk tersebut sehingga belum menemukan mouthfeel yang menyenangkan. Diperlukan pengembangan produk lebih lanjut sehingga menemukan formula yang benar-benar diterima konsumen.

\section{KESIMPULAN}

Formula cookies bekatul spirulina terbaik adalah dengan $11,1 \%$ bekatul dan spirulina 2,2\%. Dengan kadar protein yang tinggi namun masih dalam batas yang diizinkan SNI, cookies bekatul spirulina berpotensi membantu dalam pemenuhan kebutuhan protein dan gizi masyarakat. Namun beberapa kelemahan dari karakteristik kimiawi maupun sensorinya menunjukkan bahwa masih diperlukan pengembangan produk selanjutnya sehingga didapatkan formula yang lebih dapat diterima konsumen.

\section{DAFTAR PUSTAKA}

Ali, S.K. and Saleh, A.M. 2012. Spirulina an Overview. International Journal of Pharmacy and Pharmaceutical Science, 4(3): 9-15.

AOAC. 2005. Official Methods of Analysis (18th edition) Association of Official Analytical, Chemists International. Maryland, USA.

Astawan, M. Dan Febrinda, E. 2010. Potensi Dedak dan Bekatul Beras sebagai Ingridient Pangan dan Produk Pangan Fungsional. Pangan, 19(1): 14-21.

BSN. 1992. SNI 01-2973-1992: Standar Mutu Cookies. Badan Standardisasi Nasional. Jakarta. 
Christwardana, M., Nur, M.M.A. dan Hadiyanto. 2013. Spirulina platensis: Potensinya sebagai Bahan Pangan Fungsional. Review. Jurnal Aplikasi Teknologi Pangan, 2(1): 1-4.

Damayanthi, E., Kustiyah, L., Khalid, M. dan Farizal, H. 2010. Aktivitas Atioksidan Bekatul Lebih Tinggi daripada Jus Tomat dan Penurunan Aktivitas Antioksidan Serum setelah Intervensi Minuman Kaya Antioksidan. Jurnal Gizi dan Pangan, 5(3): 205-210.

Da Silva, S.C., Fernandes, I.P., Barros, L., Fernandes, Â., José Alves, M., Calhelha, R.C., Pereira, C., Barreira, J.C.M., Manrique, Y., Colla, E., Ferreira, I.C.F.R., and Barreiro, M.F. 2019. Spray-dried Spirulina Platensis as an Effective Ingredient to Improve Yogurt Formulations: Testing Different Encapsulating Solutions. Journal of Functional Foods, 60: 103427.

Ekantari, N., Marsono, M., Pranoto, Y., dan Harmayani, E. 2017. Pengaruh Media Budidaya Menggunakan Air Laut dan Air Tawar terhadap Sifat Kimia dan Fungsional Biomassa Kering Spirulina platensis. Agritech, 37(2): 173-182.

Fatkurahman, R., Atmaka, W., dan Basito. 2012. Karakteristik Sensoris dan Sifat Fisikokimia Cookies dengan Subtitusi Bekatul Beras Hitam (Oryza sativa L.) dan Tepung Jagung (Zea mays L.). Jurnal Teknosains Pangan, 1(1): 49-57.

Hu, S., Fan, X., Qi, P., and Zhang, X. 2019. Identification of Anti-Diabetes Peptides from Spirulina platensis. Journal of Functional Foods, 56: 333-341.

Kasim, R., Liputo, S.A., Limonu, M., dan Mohamad, F.P.. 2018. Pengaruh Suhu dan Lama Pemanggangan terhadap Tingkat Kesukaan dan Kandungan Gizi Snack Food Bars Berbahan Dasar Tepung Pisang Goroho dan Tepung Ampas Tahu. JTech, 6(2): 41-48.
Liu, Y. F., Xu, L.Z. Cheng, N., Lin, L.J. and Zhang, C.W. 2000. Inhibitory Effect of Phycocyanin from Spirulina platensis on the Growth of Human Leukimia K562 Cells. Journal of Applied Phycology, 12: 125130.

Park, W.S., Kim, H.J., Li, M., Lim, D.H., Kim, J., Kwak, S.S., Kang, C.M., Ferruzzi, M.G., and Ahn, M.J. 2018. Two Classes of Pigments, Carotenoids and C-Phycocyanin, in Spirulina Powder and Their Antioxidant Activities. Molecules, 23: 1-11.

Patel, M. and Naik, S.N. 2004. Gamma-oryzanol from Rice Bran Oil - A Review. Journal of Scientific \& Industrial Research, 63: 569578.

Phang, S.M., Miah, M.S., Chu, W.L. and Hashim, M. 2000. Spirulina Culture in Digested Sago Starch

Factory Waste Water. Journal of Applied Phycology, 12: 395400.

Sarbini, D., Rahmawaty, S., dan Kurnia, P. 2009. Uji Fisik, Organoleptik, dan Kandungan Zat Gizi Biskuit Tempe-Bekatul dengan Fortifikasi Fe dan Zn untuk Anak Kurang Gizi. Jurnal Penelitian Sains \& Teknologi, 10(1): 18-26.

Soni, R.A., Sudhakar, K., dan Rana, R.S. 2017. Spirulina - from Growth to Nutritional Product: A Review. Trends in Food Science \& Technology, 9: 157-171.

Susanna, D., Zakianis., Hermawati, E. dan Adi, H.K. 2007. Pemanfaatan Spirulina platensis sebagai Suplemen Protein Sel Tunggal (PST) Mencit (Musmusculus). Makara Kesehatan, 11(1): 44-49.

Wanyo, P., Chomnawang, C., and Siriamornpun, S. 2009. Substitution of Wheat Flour with Rice Flour and Rice Bran in Flake Products: Effects on Chemical, Physical and Antioxidant Properties. World Applied Sciences Journal, 7(1): 49-56. 
Wulandari, M., dan E. Handarsari. 2010. Pengaruh Penambahan Bekatul terhadap Kadar
Protein dan Sifat Organoleptik Cookies. Jurnal Pangan dan Gizi, 1(2): 55- 62. 